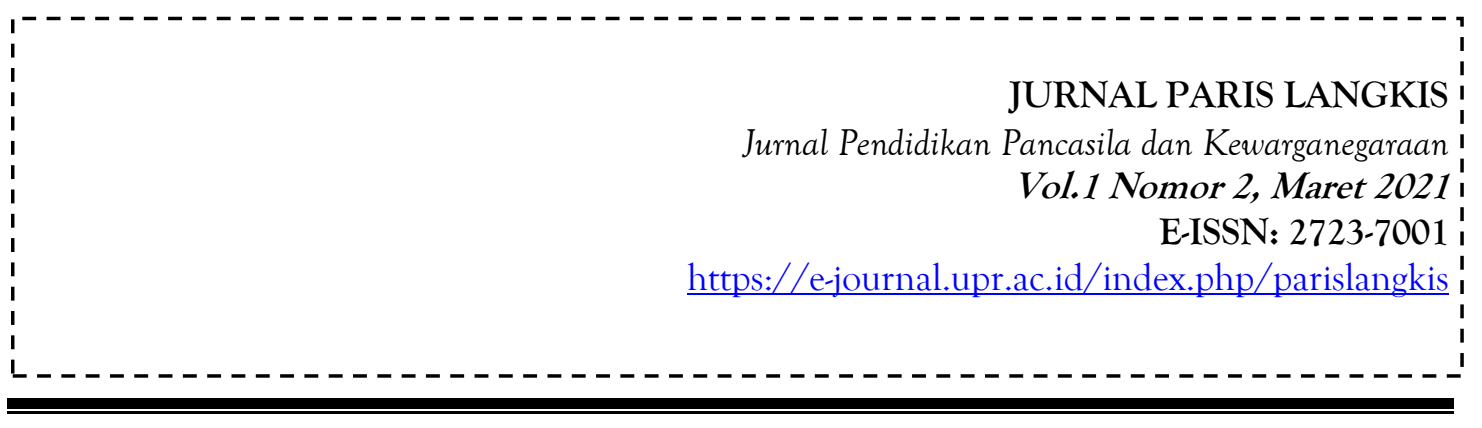

\title{
PENGARUH KOMPENSASI DAN IKLIM KERJA TERHADAP KINERJA GURU PESANTREN DI SEBERANG KOTA JAMBI
}

\author{
Lilis Suryani ${ }^{1}$, Bayu Budi Dharma ${ }^{2}$ \\ Dosen STIT Al Azhar Diniyah Jambi ${ }^{1 *}$, Guru PKP Al Hidayah Jambi ${ }^{2}$ \\ Dharma64889@gmail.com¹,Dharmalilis86@gmail.com²
}

\begin{abstract}
Abstrak
Kinerja guru merupakan salah satu faktor yang sangat menentukan keberhasilan pendidikan.Oleh karena itu kinerja guru perlu di kembangkan terus menerus agar diperoleh sember daya manusia yang bermutu dalam arti yang sebenarnya, yaitu dapat memenuhi tuntutan pekerjaannya.Pencapaian kinerja guru dipengaruhi oleh beberapa factor, diantaranya Kompensasi dan Iklim Kerja.Penelitian ini merupakan penelitian kuantitatif mengunakan metode survey.Sampel penelitian berjumlah 101 partisipan.Metode pengumpulan data yang digunakan adalah angket dan dianalisis secara analisis regresi linier berganda baik secara persial dan simultan. Hasil penelitian menunjukkan bahwa tidak terdapat pengaruh antara Kompensasi terhadap Kinerja Guru dengannilai thitung sebesar 0.648 dengan probabilitas sig $0.518>\alpha=0.05$, atau $t_{\text {hitung }}<t_{\text {table }}$ yaitu $0.648<1.985$. Terdapat Pengaruh positif dan signifikan antara Iklim kerja terhadap kinerja guru dengan nilai thitung sebesar 3.482 dengan probabilitas sig $0.01<\alpha=0.05$, atau $t_{\text {hitung }}>t_{\text {table }}$ yaitu 3.482>1.985. Dan terdapat pengaruh positif dan signifikan antara kompensasi dan iklim kerja terhadap kinerja guru pesantren di seberang kota jambi dengan nilai F-hitung sebesar 6.302 dengan probabilitas sig $0.03<\alpha=0.05$ atau $f_{\text {hitung }}>f_{\text {tabel }}$ yaitu $6.302>$ 3.09. Berdasarkan hasil penelitian ini dapat disimpulkan bahwa ada pengaruh positif dan signifikan kompensasi dan iklim kerja terhadap kinerja guru pesantren di seberang kota jambi secara simultan.
\end{abstract}

Paris Langkis

Vol.1 Nomor 2, Maret 2021 
Kata Kunci :Kompensasi, Iklim kerja, Kinerja Guru

\section{A. PENDAHULUAN}

Undang-Undang Nomor 14 tahun 2005 tentang Guru dan Dosen . Guru adalah pendidik profesional dengan tugas utama mendidik, mengajar, membimbing, mengarahkan, melatih, menilai, dan mengevaluasi peserta didik pada pendidikan anak usia dini jalur pendidikan formal, pendidikan dasar, dan pendidikan menengah.Perwujudan pendidikan formal yang baik, hanya dapat diwujudkan dengan pendidikan yang bermutu, relavan, dan berkeadilan. Pendidikan merupakan cerminan suatu bangsa yang berfungsi untuk pembangunan nasional di berbagai bidang.Sebagai intergrasi dengan system pendidikan yang islami, pendidikan harus dapat menghasilkan tenaga terdidik yang cakap, kreatif, professional agar menjadi pelakupelaku pendidik yang agamis.Sebagai manusia produktif, tenaga terdidik harus memiliki bekal kemampuan yang memadai untuk mengajar di pondok pesantren.

Sehubungan di atas, peningkatan mutu pendidikan di Indonesia adalah sebuah keniscayaan, dan tantangan besar dalam rangka meningkatkan kualitas bangsa di abad persaingan dunia ini.Berbagai upaya peningkatan mutu telah di lakukan.Menurut Supardi (2016) kinerja adalah suatu kegiatan yang dilakukan untuk melaksanakan, menyelesaikan tugas dan tanggung jawab sesuai dengan harapan dan tujuan yang telah di tetapkan. Guru formal khususnya yang mengajar di pesantren haruslah berkualitas dan berkompetensi baik dalam rangka mendapatkan hasil outcome yang baik. Untuk mewujudkan kinerja guru yang berkualitas dan berkompetensi

Isu strategis kinerja merupakan permasalahan mendasar yang mempunyai dampak positif dan negative. Apabila iklim kinerja dan kompensasi di sebuah sekolah baik. Mulai dari interaksi antara satu sama lain dan di dukung dengan lingkungan yang kondusif akan tercipta iklim yang harmoni. Sebagaimana hasil penilitian terdahulu Imam (2013) bahwa ada hubungan positif antara iklim organisasi dengan kualitas kehidupan kerja karyawan PT Aseli Dagadu Djokdja. Adapun sumbangan efektif variable iklim organisasi pada kualitas kehidupan kerja adalah sebesar $48,4 \%$, hal ini menunjukkan bahwa iklim organisasi menyumbang $48,4 \%$ terhadap kualitas kehidupan kerja

Kompensasi adalah sesuatu yang bersifat balas jasa, seberapa besar pekerjaan yang dikerjakan maka sebesar itu yang akan di dapatkan. Menurut Sutrisno (2016) bahwa para karyawan telah memberikan segala kemampuan kerjanya kepada perusahaanm, maka perusahaan sewajarnya menghargai jerih payah karyawan itu dengan cara memberi balas jasa yang setimpal kepada mereka.Menurut Bryson (2010) dalam jurnal NIESR dengan judul do salaries improve worker performance yang hasilnya

\section{Paris Langkis}

Vol.1 Nomor 2, Maret 2021 
yaitu, salah satu cara untuk meningkatkan kinerja itu dengan karir, pendapatan yang lebih dan memberikan pelatihan di luar pekerjaan. Selanjutnya menurut penelitian terdahulu Muguongo (2015) dalam jurnal Effects of Compensation on Job Satisfaction Among Secondary School teachers in Maara Sub - County of Tharaka Nithi County, Kenya bahwa para guru itu sangat tidak puas dengan semua aspek kompensasi yang mereka terima. Dengan demikian apabila kepuasan kerja guru tergangu maka akan mempengaruhi kinerja mereka di sekolah.

Iklim kerja adalah suatu keadaan dimana terdapat hubungan harmonis yang terjadi di sekolah. Menurut Supardi (2016) Iklim adalah keadaan sekitar sekolah / madrasah dan suasana yang "sunyi dan nyaman" yang sesuai dan kondusif untuk pembelajaran yang dapat meningkatkan prestasi akademik. Selanjutnya menurut Triatna (2016) iklim sekolah merupakan suatu tone (suasana) yang dirasakan oleh pegawai suatu organisasi / sekolah berdasarkan interaksi dirinya dengan lingkungan, baik lingkungan fisik, maupun lingkungan social.

Berdasarkan masalah-masalah yang ada penulis mencoba melukakan pengamatan ( observasi) dan wawancara awal dengan guru-guru yang berada di pesantren Seberang,(1). Beberapa guru yang mempunyai kinerja sedang, sehingga mempengaruhi proses pembelajaran hal ini disebabkan oleh kurang adanya persiapan dalam mengajar seperti tidak membawa RPP ketika ingin mengajar, pelaksanaan pembelajaran yang monoton, kurang adanya kemauan untuk maju dan meraih prestasi. (2). pemberian kompensasi yang diberikan oleh pondok pesantren adalah dengan sistem remunerasi. Remunerasi adalah imbalan langsung terdiri dari gaji/ upah, tunjangan jabatan, tunjangan khusus, bonus yang dikaitkan atau tidak dikaitkan dengan prestasi kerja dan kinerja organisasi, insentif sebagai penghargaan prestasi, dan berbagai jenis bantuan yang diberikan secara rutin. Imbalan tidak langsung terdiri dari dana social, rumah bagi guru, study tour ke tempat-tempat wisata dan lain sebagainya. Namun dalam pelaksanaanya, pemberian kompensasi tersebut masih menyimpan masalah yaitu besarnya kompensasi yang diberikan kepada guru belum mencukupi kebutuhan dari guru tersebut. (3). Rendahnya iklim kerja, hal ini dapat dilihat dari belum tercipta iklim kerja yang kondusif disebabkan oleh udara atau bau yang menyengat yang disebabkan oleh pabrik karet yang dekat dengan pesantren, sarana dan prasarana yang belum memadai seperti bangunan sekolah, ruang guru dan ventilasi udara, dan kurang terjalinnya hubungan harmonis diantara guru sehingga berdampak terhadap kinerja guru di pesantren.

Berdasarkan latar belakang di atas, maka rumusan masalah dari penelitian adalah sebagai berikut

1. Apakah terdapat pengaruh yang signifikan kompensasi terhadap kinerja guru pesantren di Seberang Kota Jambi?

\section{Paris Langkis}

Vol.1 Nomor 2, Maret 2021 
2. Apakah terdapat pengaruh yang signifikan iklim kerja terhadap kinerja guru pesantren di Seberang Kota Jambi?

3. Apakah terdapat pengaruh yang signifikan kompensasi, iklim kerja secara bersaman terhadap kinerja guru pesantren di Seberang Kota Jambi?

Berdasarkan rumusan masalah di atas, maka tujuan dalam penelitian ini adalah untuk mengetahui dan menganalisis sebagai berikut.

1. Untuk mengetahui pengaruh yang signifikan kompensasi terhadap kinerja guru pesantren di Seberang Kota Jambi.

2. Untuk Mengetahui pengaruh yang signifikan iklim kerja terhadap kinerja guru pesantren di Seberang Kota Jambi.

3. Untuk Mengetahui pengaruh yang signifikan kompensasi, iklim kerja dan bersama-sama terhadap kinerja guru pesantren di Seberang Kota Jambi.

\section{B. KERANGKA TEORITIS}

\section{KOMPENSASI}

Suwatno (2016)Kompensasi adalah imbalan yang diterima atas jasa yang telah diberikan kepada perusahaan memungkinkan karyawan untuk mempertahankan harkat dan martabatnya dan juga dapat memungkinkan karyawan mempertahankan taraf hidup yang wajar, layak dan mandiri tanpa tergantung kepada orang lain terutama dalam pemenuhan kebutuhan-kebutuhan hidupnya. Sutrisno (2016)Kompensasi adalah semua jenis penghargaan yang berupa uang atau bukan uang yang diberikan kepada karyawan secara layak dan adil atas jasa mereka dalam mencapai tujuan perusahaan.

Soekidjo (2015) Kompensasi sangat penting bagi karyawan itu sendiri sebagai induvidu, karena besarnya kompensasi merupakan pencerminan atau ukuran nilai pekerjaan itu sendiri. Menurut Dessler ( 2013) Employee compensation includes all forms of pay going to employees and arising from their employment. It has two main components, direct financial payments (wages, salaries, incentives, commissions, and bonuses) and indirect financial payments ( financial benefits like employer-paid insurance and vacation).

\section{IKLIM KERJA}

Wahab (2011)Budaya Organisasi merupakan norma-norma dan nilai-nilai yang mengarahkan perilaku anggota organisasi. Supardi (2014)Iklim kerja sekolah adalah keadaan sekitar sekolah dan suasana yang sunyi dan nyaman yang sesuai dan kondusif untuk pembelajaran yang dapat meningkatkan prestasi akademik. Menurut Triatna (2016) Iklim sekolah merupakan tone (suasana) yang dirasakan oleh pegawai suatu organisasi/ sekolah berdasarkan interaksi dirinya dengan lingkungannya, baik lingkungan fisik maupun lingkungan social.Fenwick (2006)Friendships are vital to

\section{Paris Langkis}

Vol.1 Nomor 2, Maret 2021 
children because they serve as emotional resources for having fun and adapting to stress, expand cognitive resources for problem solving, provide the context for developing social skills, and are the forerunner of all other relationships.Menurut Owen (1991) Iklim sebagai karakteristik keseleruhan dari lingkungan yang berada di dalam lingkungan sekolah yang terbagi atas empat dimensi, yakni (1) Ekologi, (2) Miliu, (3) Sistem Sosial, (4) Budaya.

\section{KINERJA GURU}

Supardi (2016) "kinerja merupakan suatu kegiatan yang dilakukan untuk melaksanakan, menyelesaikan tugas dan tanggung jawab sesuai dengan harapan dan tujuan yang telah di tetapkan. Jones (2007) "Performance means both behaviours and results. Behaviours emanate from the performer and transform performance from abstraction to action. Not just the instruments for results, behaviours are also outcomes in their own right - the product of mental and physical effort applied to tasks - and can be judged apart from result. Menurut (Donni: 2014) "Guru yang memiliki level kinerja tinggi merupakan guru yang memiliki produktifitas kerja sama dengan di atas standar yang ditentukan.

Menurut Wahyudi (2012) "Penilaian kinerja seseorang adalah untuk mengetahui seberapa besar mereka bekerja melalui suatu sistem formal dan terstruktur, seperti menilai, mengukur, dan mempengaruhi sifat-sifat yang berkaitan dengan pekerjaan, perilaku, dan hasil termasuk tingkat ketidakhadiran. Menurut Wibowo (2008) "Suatu proses kinerja apabila telah selesai dilaksanakan, akan memberikan hasil kinerja atau prestasi kerja. Menurut Mulyasa (2010) "Kinerja mempunyai hubungan erat dengan produktivitas karena merupakan indikator dalam menentukan usaha untuk mencapai produktivitas yang tinggi.

\section{METODE PENELITIAN}

Penelitian yang di lakukan peniliti adalah dengan menggunakan pendekatan kuantitatif.Hal ini karena penyelesaian dibutuhkan waktu yang relative singkat, dan instrument pengumpulan data yang digunakan angket, wawancara dan lain sebagainya, tidak harus peniliti sendiri dari setiap objek memiliki keterkaitan dan hubungan di dalamnya. Data yang akan diteliti adalah guru pesantren yang berjumlah 187 guru dan sampel 128 responden. penentuan sampel untuk jumlah guru di lakukan dengan rumus Slovin dalam Ridwan (2005) Rumus dimaksud adalah sebagai berikut

\begin{tabular}{|c|c|}
\hline $\mathrm{N}=$ & $\mathrm{N}$ \\
\hline & $\begin{array}{c}\mathrm{S} \\
1{ }^{2}+1\end{array}$ \\
\hline
\end{tabular}

\section{Paris Langkis}

Vol.1 Nomor 2, Maret 2021 
$\mathrm{N} \quad=$ Jumlah Populasi

$\mathrm{d}=$ Presisi atau batas toleransi kesalahan pengambilan sampel yang digunakan $(0,05)$

Hasil yang diperoleh dalam menentukan jumlah sampel sebagai berikut :

$\mathrm{n}=\quad \begin{array}{r}\frac{187}{187\left(0,05^{22}+1\right.} \\ =\frac{187}{1.46} \\ =128\end{array}$

Berdasarkan perhitungan di atas maka peneliti menetapkan anggota sampel yang digunakan dalam metode penelitian ini adalah 128 orang.Untuk memperoleh data yang lengkap dan teliti dalam penelitian, maka peniliti menggunakan tehknik pengumpulan data yang menggunakkan angket (questionare). Penelitian yang dilakukan di Pesantren Seberang Kota Jambi, dan dilaksanakan mulai

Teknik pengumpulan data dilakukan dengan menggunakan angket (questioner).Teknik analisis data yang digunakan yaitu analisis deskriptif dan kuantitatif.Teknik analisis deskriptif digunakan untuk mendeskripsikan variabel Kompensasi $\left(\mathrm{X}_{1}\right)$, Iklim Kerja $\left(\mathrm{X}_{2}\right)$ dan Kinerja Guru (Y).dan untuk menguji dan menganalisa data dengan perhitungan angka-angka dan kemudian menarik kesimpulan dari pengujian tersebut. Dengan menggunakan analisis regresi berganda dengan bantuan computer program SPSS 20.0. pengujian dilakukan dengan menggunakan significance level taraf nyata $0,05(a=5 \%)$.

\section{HASIL DAN PEMBAHASAN}

Hasil penelitian ini pada uji validitas di gunakan oleh peneliti untuk mengukur data yang telah didapat setelah penelitian yang merupakan data yang valid dengan alat ukur yang digunakan adalah questioner.Valid artinya data yang diperoleh melalui questioner dapat menjawab tujuan penelitian.Questioner yang disebar di PPM Al hidayah dengan jumlah responden 20 guru.Pengujian validitas dilakukan dengan menggunakan Program SPSS 20.0 for windows.Dengan membandingkan nilai $r$ hitung dengan $r$ table. Nilai korelasi skor total $\left(\mathrm{r}_{\text {hitung }}\right)$ per item yang diperolah harus lebih besar dari nilai rtabel $\left(r_{\text {hitung }} r_{\text {tabel }}\right)$ dengan taraf signifikan $5 \%$ yaitu sebesar 0.444.diketahui pada variable kompensasi (X1) butir pertanyaan yang gugur no; 2, sisanya valid dari 10 butir pertanyaan. Variable iklim kerja (x2) butir pertanyaan yang gugur no; 6 , sisanya valid dari 15 pertanyaan. Variable kinerja guru (Y) butir pertanyaan yang gugur no;10, 12, sisanya valid dari 15 pertanyaan. Dengan ini keseluruhan jumlah pertanyaan 36.

a. Uji realibilitas

Paris Langkis

Vol.1 Nomor 2, Maret 2021 
Neuman (2013) menjelaskan bahwa "Uji Reliabilitas (measurement reliability) adalah kemampuan diandalkan atau konsistensi dari ukuran suatu variabel”(p. 234). Uji realibilitas dari variable kompensasi, iklim kerja dan kinerja guru. Dapat dilihat dari table berikut ;

Tabel hasil Uji Reliabilitas

\begin{tabular}{|l|l|l|l|l|}
\hline No & Variabel & Cronbach's alpha & Nilai standar & Keputusan \\
\hline 1 & Kompensasi (X1) & 0,756 & 0,60 s.d 80 & Reliable \\
\hline 2 & Iklim Kerja (X2) & 0,786 & 0,60 s.d 80 & Reliable \\
\hline 3 & Kinerja Guru (Y) & 0,820 & 0,80 s.d 1,00 & Sangat Reliable \\
\hline
\end{tabular}

Sumber; Hasil pengolahan data dengan SPSS 20.0

\section{b. Uji Normalitas}

Tujuan uji normalitas adalah untuk mengetahui apakah data dari sampel penelitian berasal dari populasi yang berdistribusi normal atau tidak. Uji normalitas dilakukan menggunakan teknik uji Liliefors atau dalam program SPSS disebut dengan Kolmogrov-Smirnov. Kriteria dari uji normalitas adalah bahwa data berdistribusi normal jika nilai $\mathrm{L}_{\text {hitung }}<\mathrm{L}_{\text {tabel }}$ atau nilai signifikansi $>0,05$. Dalam penelitian ini data menunjukkan berdistribusi normal, hal ini terlihat dari nilai signifikan yang lebih besar dari 0,05. Untuk lebih jelas dapat dilihat pada tabel di bawah ini:

\begin{tabular}{|c|c|c|c|c|}
\hline \multicolumn{5}{|c|}{ One-Sample Kolmogorov-Smirnov Test } \\
\hline & & Kompensasi(X1) & Iklim Kerja (X2) & Kinerja Guru $(Y)$ \\
\hline \multicolumn{2}{|l|}{$N$} & 101 & 101 & 101 \\
\hline \multirow[t]{2}{*}{ Normal Parameters ${ }^{\mathrm{a}, \mathrm{b}}$} & Mean & 32.9208 & 51.1782 & 52.1584 \\
\hline & Std. Deviation & 4.43325 & 6.96907 & 4.26786 \\
\hline \multirow[t]{3}{*}{ Most Extreme Differences } & Absolute & .131 & .225 & .267 \\
\hline & Positive & .077 & .143 & .104 \\
\hline & Negative & -.131 & -.225 & -.267 \\
\hline \multicolumn{2}{|l|}{ Kolmogorov-Smirnov Z } & 1.313 & 2.261 & 2.687 \\
\hline \multicolumn{2}{|l|}{ As ymp. Sig. (2-tailed) } & .064 & .000 & .000 \\
\hline
\end{tabular}

\section{c. Uji Linieritas}

Tujuan uji linieritas adalah untuk mengetahui bagaimana bentuk hubungan antara satu variable bebas dengan satu variable terikat. Adapun hasil uji linieritas dan keberartian regresi linier yang dilakukan menggunakan alat bantu SPSS versi 20.0. Berdasarkan hasil uji linearitas diketahui bahwa nilai signifikansi dari deviation from linearity variabel kompensasi adalah 0,499, nilai signifikansi dari deviation from linearity variabel iklim kerja adalah 0,000. Mengacu pada kriteria pengujian dapat dinyatakan bahwa nilai signifikansi semua variabel lebih besar dari alpha (5\%). Dengan

\section{Paris Langkis}

Vol.1 Nomor 2, Maret 2021 
demikian dapat disimpulkan bahwa garis regresi tersebut berbentuk linear sehingga dapat digunakan untuk memprediksi besarnya variabel kinerja guru. Berikut disajikan ringkasan hasil uji linearitas :

Tabel Hasil Uji Linearitas Kompensasi

\begin{tabular}{|c|c|c|c|c|c|c|c|}
\hline \multicolumn{8}{|c|}{ ANOVA Table } \\
\hline & & & $\begin{array}{l}\text { Sum of } \\
\text { Squares }\end{array}$ & $\mathrm{df}$ & $\begin{array}{l}\text { Mean } \\
\text { Square }\end{array}$ & $\mathrm{F}$ & Sig. \\
\hline \multirow{5}{*}{$\begin{array}{l}\text { Kinerja Guru } \\
(Y) * \\
\text { Kompensasi } \\
(\mathrm{X} 1)\end{array}$} & \multirow{3}{*}{$\begin{array}{l}\text { Between } \\
\text { Groups }\end{array}$} & (Combined) & 455.957 & 20 & 22.798 & 1.336 & .182 \\
\hline & & Linearity & 7.857 & 1 & 7.857 & .460 & .499 \\
\hline & & Deviation & 448.100 & 19 & 23.584 & 1.382 & .160 \\
\hline & \multicolumn{2}{|c|}{ Within Groups } & 1365.508 & 80 & 17.069 & & \\
\hline & \multicolumn{2}{|l|}{ Total } & 1821.465 & 100 & & & \\
\hline
\end{tabular}

TabelHasil Uji Linearitas Iklim Kerja

ANOVA Table

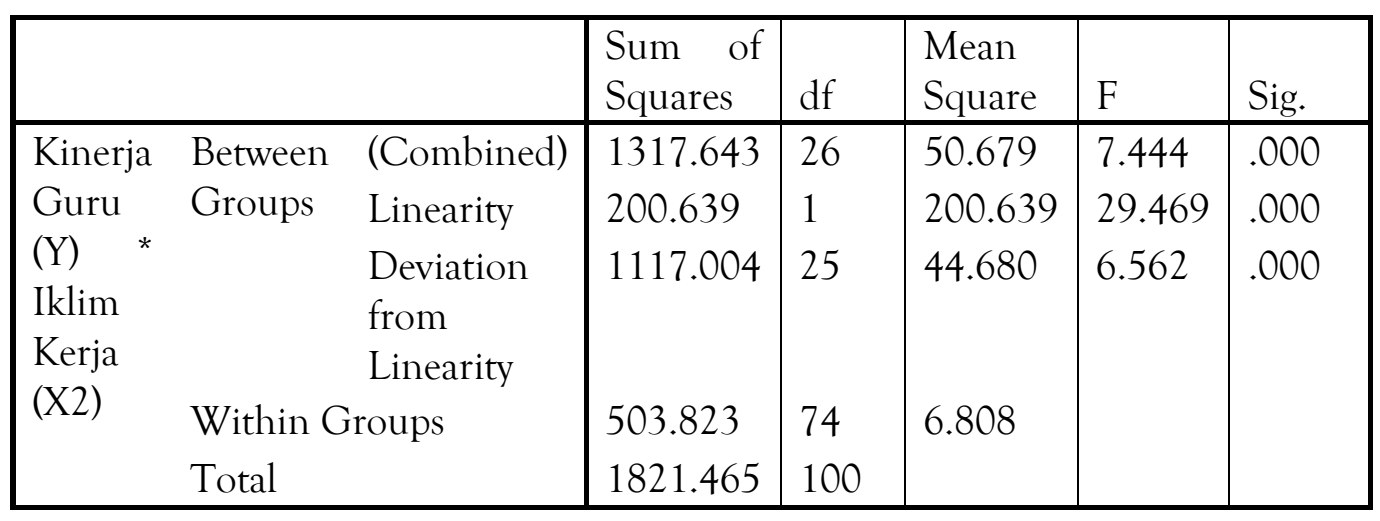

\section{d. Hasil Analisis Linear Berganda}

Pengaruh kompensasi dan iklim kerja terhadap kinerja guru pesantren dalam persamaan regresi berganda dapat dilihat dari nilai kofisien B pada table berikut:

Tabel koefisien Analisis Regresi Berganda 


\begin{tabular}{|c|c|c|c|c|c|c|}
\hline \multicolumn{7}{|c|}{ Coefficients $^{a}$} \\
\hline \multirow{2}{*}{\multicolumn{2}{|c|}{ Model }} & \multicolumn{2}{|c|}{$\begin{array}{c}\text { Unstandardized } \\
\text { Coefficients }\end{array}$} & \multirow{2}{*}{$\begin{array}{c}\text { Standardized } \\
\text { Coefficients }\end{array}$} & \multirow[b]{2}{*}{$\mathrm{t}$} & \multirow[b]{2}{*}{ Sig. } \\
\hline & & B & Std. Error & & & \\
\hline \multirow[t]{3}{*}{1} & (Constant) & 39.825 & 4.232 & & 9.410 & .000 \\
\hline & Kompensasi & .059 & .092 & .062 & .648 & .518 \\
\hline & Iklim Kerja (X2) & .203 & .058 & .331 & 3.482 & .001 \\
\hline
\end{tabular}

a. Dependent Variable: Kinerja Guru (Y)

Bedasarkan output tersebut dapat kita lihat nilai t-hitung yang diperoleh setiap variabel. Untuk membuat kesimpulan menerima atau menolak Hipotesis Alternatif, terlebih dahulu harus ditentukan nilai-nilai t-tabel yang akan digunakan dan tingkat signifikansi yang digunakan. Dengan menggunakan tingkat signifikansi 5\%.Hasil pengujian pengaruh setiap variabel independent (Kompensasi Dan Iklim Kerja) terhadap variabel dependent (Kinerja Guru) di Pondok Pesantren Seberang Kota Jambi sebagai berikut:

\section{e. Pengaruh Kompensasi Terhadap Kinerja Guru}

Berdasarkan output diketahui nilai t-hitung sebesar 0.648 dengan probabilitas

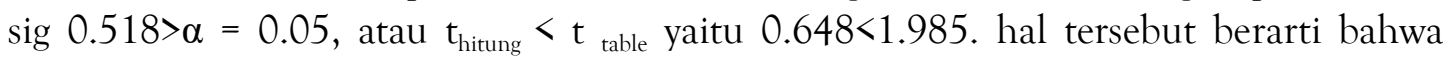
hipotesis alternative $(\mathrm{Ha})$ diterima dan dapat disimpulkan bahwa kompensasi secara parsial tidak mempunyai pengaruh yang signifikan terhadap kinerja guru pesantren. Hal ini menunjukan bahwa kompensasi tidak berpengaruh terhadap kinerja guru pesantren.

\section{f. PengaruhIklim Kerja terhadap Kinerja Guru}

Berdasarkan output diketahui nilai t-hitung sebesar 3.482 dengan probabilitas sig $0.01<\alpha=0.05$, atau $t_{\text {hitung }}>t$ table yaitu 3.482>1.985. hal tersebut berarti bahwa hipotesis nol $\left(\mathrm{H}_{0}\right)$ diterima $(\mathrm{Ha})$ ditolak dan dapat disimpulkan bahwa iklim kerja secara parsial mempunyai pengaruh yang signifikan terhadap kinerja guru pesantren. Hal ini menunjukan bahwa Iklim kerja berpengaruh terhadap kinerja guru pesantren.

\section{g. Pengujian Hipotesis secara Simultan (Uji F)}

Untuk mengetahui signifikan pengaruh variabel-variabel bebas secara bersamasama atas suatu variabel terikat digunakan uji F. Hasil pengujian hipotesis secara simultan dengan menggunakan SPSS 20 adalah sebagai berikut:

\section{Tabel Uji Hipotesis Secara Simultan}

\section{Paris Langkis}

Vol.1 Nomor 2, Maret 2021 


\begin{tabular}{|c|c|c|c|c|c|c|}
\hline \multicolumn{7}{|c|}{ ANOVA $^{a}$} \\
\hline \multicolumn{2}{|c|}{ Model } & $\begin{array}{l}\text { Sum of } \\
\text { Squares }\end{array}$ & $d f$ & Mean Square & $\mathrm{F}$ & Sig. \\
\hline \multirow[t]{3}{*}{1} & Regression & 207.565 & 2 & 103.782 & 6.302 & $.003^{b}$ \\
\hline & Residual & 1613.901 & 98 & 16.468 & & \\
\hline & Total & 1821.465 & 100 & & & \\
\hline
\end{tabular}

a. Dependent Variable: Kinerja Guru $(Y)$

b. Predictors: (Constant), Iklim Kerja (X2), Kompensasi (X1)

Sumber Data Primer diolah, 2018

Berdasarkan output tersebut dapat diketahui bahwa nilai F-hitung sebesar 6.302 dengan probabilitas sig $0.03<\alpha=0.05$ atau $f_{\text {hitung }}>f_{\text {tabel }}$ yaitu 6.302> 3.09. hal tersebut berarti bahwa hipotesis nol $\left(\mathrm{H}_{0}\right)$ diterima $(\mathrm{Ha})$ ditolak dan dapat disimpulkan bahwa kompensasi dan iklim kerja secara simultan berpengaruh signifikan terhadap kinerja guru pesantren. secara parsial mempunyai pengaruh yang signifikan terhadap kinerja guru pesantren. Hal ini menunjukan bahwa kompensasi dan Iklim kerja secara simultan berpengaruh terhadap kinerja guru pesantren.

\section{h. Determinasi Kinerja Guru}

Determinasi kompensasi dan iklim kerja terhadap kinerja guru. Dari hasil perhitungan dengan SPSS 20.0 besarnya kontribusi variabel kompensasi $\left(\mathrm{X}_{1}\right)$, Iklim Kerja $\left(\mathrm{X}_{2}\right)$ terhadap Kinerja Guru $(\mathrm{Y})$ dalam artian dianalisis kemampuan variabel prediktor $\left(\mathrm{X}_{1}\right)$ dan $\left(\mathrm{X}_{2}\right)$ dalam memprediksi variabel kriteriumnya. Dari hasil penelitian ini diperoleh koefesien determinasi $\left(\mathrm{R}_{2}\right)$ sebagaimana dijelaskan pada tebel berikut:

Tabel Koefesien Determinasi Regresi kompensasi $\left(\mathrm{X}_{1}\right)$, Iklim Kerja $\left(\mathrm{X}_{2}\right)$ terhadap Kinerja Guru (Y)

\begin{tabular}{|c|c|c|c|c|}
\hline \multicolumn{5}{|c|}{ Model Summary } \\
\hline Model & $\mathrm{R}$ & R Square & $\begin{array}{l}\text { Adjusted R } \\
\text { Square }\end{array}$ & $\begin{array}{l}\text { Std. Error of } \\
\text { the Estimate }\end{array}$ \\
\hline 1 & $.338^{\mathrm{a}}$ & .114 & .096 & 4.05812 \\
\hline
\end{tabular}

a. Predictors: (Constant), Iklim Kerja (X2), Kompensasi (X1)

$\mathrm{R}$ menunjukkan regresi antara kompensasi dan iklim kerja terhadap kinerja guru yaitu 0,338. Adapun $\mathrm{R}$ Square pada tabel di atas menunjukkan nilai koefesien determinasi kompensasi dan iklim kerja terhadap kinerja guru sebesar 0,114 atau sebesar $11.4 \%$. Dengan demikian, berarti bahwa kinerja guru dapat dijelaskan oleh

\section{Paris Langkis}

Vol.1 Nomor 2, Maret 2021 
variable kompensasi dan iklim kerja atau secara praktis dapat dikatakan bahwa kontribusi kompensasi dan iklim kerja terhadap kinerja guru adalah $11.4 \%$. Sisanya $88.6 \%$ dipengaruhi oleh variable lain yang tidak diikutsertakan dalam penelitian ini.

\section{E. PEMBAHASAN}

Pada pembahasan kali ini akan di analisis hasil temuan peneliti terhadap kesusaian teori, pendapat, maupun penelitian terdahulu yang telah dikemukakan serta pola perilaku yang harus dilakukan untuk mengatasi hal tersebut. Adapun tiga bagian utama yang dibahas dan dianalisis hasil temuan penelitian sebagai berikut;

\section{1) Pengaruh Kompensasi Terhadap Kinerja Guru Di PesantrenSeberang Kota Jambi.}

Dari hasil pengujian terlihat bahwa pengaruh variable kompensasi terhadap kinerja guru di peroleh nilai t-hitung sebesar 3.482 dengan probabilitas sig $0.518>\alpha=$ 0.05 , atau $t_{\text {hitung }}<\mathrm{t}$ table yaitu $3.482<1.985$. hal tersebut berarti bahwa hipotesis alternative (Ha) diterima Hipotesis nol ditolak (Ho), dapat disimpulkan bahwa kompensasi secara parsial tidak mempunyai pengaruh yang signifikan terhadap kinerja guru pesantren. Hasil penelitian sebelumnya (Haryanto, Harja, Putri, Supawal, \& Amin, 2018) dengan implikasinya bahwasanya mengajar di pesantren, tidak hanya tentang uang dan faktor materi lebih kepada kesenangan dalam mengajar.Guru-guru di pesantren seberang mengajar dengan penuh semangat. Mereka yang mengajar dan mengabdikan dirinya kepada Pesantren mayoritas berdomisili di dekat pesantren yang tujuannya tidak hanya mencari materi tetapi lebih kepada keberkahan hidup dan mengabdi kepada masyarakat. Berdasarkan uraian di atas maka tidak terdapat keterkaitan antara kompensasi dengan kinerja guru. Artinya kompensasi yang diberikan tidak mempengaruhi kinerja guru di pesantren seberang kota jambi.

\section{2) Pengaruh Iklim kerja terhadap Kinerja Guru di Pesantren SeberangKota Jambi.}

Dari hasil pengujian terlihat bahwa pengaruh variable iklim kerja terhadap kinerja guru di peroleh nilai t-hitung sebesar 0.648 dengan probabilitas sig $0.01<\alpha=$ 0.05 , atau $t_{\text {hitung }}>t_{\text {table }}$ yaitu 3.482> 1.985. hal tersebut berarti bahwa hipotesis nol $\left(\mathrm{H}_{0}\right)$ diterima $(\mathrm{Ha})$ ditolak dan dapat disimpulkan bahwa iklim kerja secara parsial mempunyai pengaruh yang signifikan terhadap kinerja guru pesantren.temuan penelitian sebelumya Yunita (2013). Bahwa Hubungan iklim organisasi dengan motivasi kerja pegawai dinas pendidikan pemuda dan olahraga kabupaten solok dalam katagori baik. Ekologi, miliu, system social dan budaya. oleh karna itu Iklim kerja sangat dibutuhkan untuk meningkatkan kinerja dan prestasi guru. Iklim kerja merupakan salah satu faktor yang ikut menentukan tinggi rendahnya kinerja seorang Guru.

\section{Paris Langkis}

Vol.1 Nomor 2, Maret 2021 


\section{3) Pengaruh Kompensasi, Iklim Kerja Tehadap Kinerja Guru Di Pesantren Seberang Kota Jambi.}

Dari hasil pengujian tentang pengaruh secara simultan kompensasi dan iklim kerja terhadap kinerja guru diperoleh nilai F-hitung sebesar 6.302 dengan probabilitas sig $0.03<\alpha=0.05$ atau $f_{\text {hitung }}>f_{\text {tabel }}$ yaitu 6.302> 3.09. hal tersebut berarti bahwa hipotesis nol $\left(\mathrm{H}_{0}\right)$ diterima $(\mathrm{Ha})$ ditolak dan dapat disimpulkan bahwa kompensasi dan iklim kerja secara simultan berpengaruh signifikan terhadap kinerja guru pesantren. Dari hasil pengujian tentang pengaruh secara simultan kompensasi dan iklim kerja terhadap kinerja guru diperoleh nilai F-hitung sebesar 6.302 dengan probabilitas sig $0.03<\alpha=0.05$ atau $f_{\text {hitung }}>f_{\text {tabel }}$ yaitu 6.302> 3.09. hal tersebut berarti bahwa hipotesis nol $\left(\mathrm{H}_{0}\right)$ diterima $(\mathrm{Ha})$ ditolak dan dapat disimpulkan bahwa kompensasi dan iklim kerja secara simultan berpengaruh signifikan terhadap kinerja guru pesantren. penelitian yang dilakukan oleh Batubara (2016) Tentang "Pengaruh lingkungan kerja, kompensasi, dan komitmen terhadap kinerja guru madrasah aliyah negeri (MAN) di Kota Medan terdapat hubungan yang positif dan signifikan antara kesemua variabel independen terhadap variabel dependen.Hasil penelitian secara deskriptif menunjukkan bahwa lingkungan kerja dan kompensasi tergolong kategori tinggi, sedangkan gambaran komitmen dan kinerja guru tergolong sangat tinggi, ada pengaruh yang positif dan signifikan lingkungan kerja terhadap kinerja guru.

\section{F. KESIMPULAN}

Bedasarkan analisis hasil penelitian dan pembahasan yang telah diuraikan sebelumnya kompensasi di pesantren seberang kota jambi masuk dalam katagori tinggi, Iklim kerja di pesantren seberang kota jambi masuk dalam katagori baik. Kinerja guru di pesantren seberang kota jambi masuk dalam katogori tinggi. Maka dapat disimpulkan sebagai berikut :

1. Tidak terdapat pengaruh antara kompensasi dengan kinerja guru. Artinya kinerja guru tidak selalu ditentukan oleh kompensasi.

2. Terdapat pengaruh antara Iklim kerja dengan kinerja guru. Artinya makin tinggi Iklim kerja maka makin tinggi pula hasil kinerja guru tersebut dan sebaliknya kinerja guru yang kinerjanya rendah disebabkan iklim kerjanya rendah.

3. Terdapat pengaruh antara kompensasi dan iklim kerja dengan kinerja guru. Artinya makin tinggi kompensasi dan semakin baik iklim kerja maka makin tinggi pula kinerja guru tersebut.

Paris Langkis

Vol.1 Nomor 2, Maret 2021 


\section{DAFTAR PUSTAKA}

Arifin, H. (2011). Ilmu pendidikan Islam. Jakarta: PT. Bumi Aksara.

Batubara, A. A. (2016). Pengaruh lingkungan kerja, kompensasi, dan komitmen terhadap kinerja guru MAN. Malang: Universitas Islam Negri Maulana Malik Ibrahim.

Beardwell, J. (2017). Human resource management. United Kindom: Pearson Education.

Creswell, J. W. (2012). Research design qualitative, quantitative, and mixed methods approaches $\left(2^{\text {nd }} e d.\right)$. Thousand Oaks, California: Sage Publication.

Creswell, J. W. (2012). Educational research : Planning, conducting, and evaluating quantitative and qualitative research ( $4^{\text {th }}$ ed.). Boston: Pearson Education, Inc.

Dessler, G. (2013). Human resource management. USA: Pearson Education.

Fenwick, W. (2006).Encyclopedia educational leadership and administration. The United States of America: Sage Publication.

Foot, M., Hook. C,.\& Jenkins.A. (2016).Introducing human resource management $\left(7^{\text {th }} \mathrm{ed}\right)$. United Kingdom: Pearson Education.

Given, L. (2008). The sage ecyclopedia of qualitative research methods. Thousand Oaks Sage, California: Sage Publication.

Haryanto, E., Harja, H., Putri, .D.M., Supawal., Amin, M. (2018). Why choose volunteering in an Islamic boarding school? Documenting the undocumented voluntary teaching motives.Journal of Islamic Education, 23(1).

Mangkunegara, A. (2008). Manajemen sumber daya manusia. Bandung: PT. Remaja Rosda Karya.

Middlewood, D, Carol, C. (2001). Managing teacher appraisal and performance. USA: Routledge.

Mulyawan, J. U. (2015). Ilmu pendidikan Islam. Jakarta: PT. Raja Grafindo Persada.

Notoatmojo, P. D. (2015). Pengembangan sumber daya manusia. Jakarta: PT Rineka Cipta.

Priansa, D. J. (2014). Kinerja dan profesionalisme guru. Bandung: Alfabeta.

Seidman, I. (1999). The essential career guide to becoming a middle and high school teacher. USA: Bergin \& Garvey.

Simmons, A. B. (2010). Do salaries improve worker Performance? national institute of economic and social research, Discussion Paper, 366.

Sobirin. (2018). Kepala sekolah, guru dan pembelajaran. Bandung: Nuansa.

Soetopo, H. (2010). Perilaku organisasi. Bandung: PT Remaja Rosdakarya.

Stronge, J. H. (2007). Qualities of effective teacher. Alexandria: Asco.

Supardi. (2016). Kinerja guru. Jakarta: PT. Rajagrafindo Persada.

Surya, M. (2013). Psikologi guru . Bandung: Alfabeta .

Sutrisno, E. (2016). Manajemen sumber daya manusia. Jakarta: Prenada Media Grup.

Suwatno. (2016). Manajemen SDM dalam organisasi publik dan bisnis. Bandung: Alfabeta.

\section{Paris Langkis}

Vol.1 Nomor 2, Maret 2021 
Triatna, C. (2016). Perilaku organisasi. Bandung: PT Remaja Rosda Karya.

Wahab, A. A. (2011). Anatomi organisasi dan kepemimpinan pendidikan. Bandung: Alfabeta.

Paris Langkis

Vol.1 Nomor 2, Maret 2021 